\title{
Upaya promotif peningkatan kesadaran kesehatan reproduksi: Metode penyuluhan pada komunitas yang terpapar gas buang karbon
}

\author{
Joko Marwoto, Lusia Hayati, Sri Nita, Rachmat Hidayat, Septi Purnamasari, \\ Rara Inggarsih
}
Bagian Biologi, Fakultas Kedokteran Universitas Sriwijaya, Palembang, Indonesia E-mail : dr.rachmat.hidayat@gmail.com

\begin{abstract}
Abstrak
Kecenderungan peningkatan jumlah kendaraan bermotor dapat mengakibatkan kualitas udara makin menurun. Semakin meningkatnya jumlah kendaraan bermotor di jalanan ibu kota-kota besar dengan berbagai merk dan tipe akan meningkatkan konsumsi pemakaian bahan bakar minyak dan menimbulkan efek pencemaran udara, dimana salah satu dampak serius terganggunya kesehatan reproduksi pria. Upaya promotif dengan Teknik ceramah diskusi dan tanya jawab dilakukan pada komunitas dengan paparan emisi gas buangan kendaraan yang cukup serius, yakni para penegmudi ojek daring. Sebanyak 30 orang pengendara ojek daring telah menerima manfaat dan solusi guna meningkatkan derajat kesehatan reproduksi pria.
\end{abstract}

Kata Kunci : Ojek, Reproduksi Pria, Online

\begin{abstract}
Promotive Efforts to Increase Reproductive Health Awareness: Counseling Methods in Communities Exposed to Carbon Discharge. The tendency to increase the number of motorized vehicles can result in decreased air quality. The increasing number of motorized vehicles on the streets of major cities with various brands and types will increase the consumption of fuel oil and cause the effects of air pollution, which is one of the serious impacts of disrupting male reproductive health. Promotive efforts with discussion and question and answer lecture techniques were carried out to communities with serious exposure to vehicle exhaust emissions, namely online motorcycle taxi drivers. As many as 30 online motorcycle taxi riders have received benefits and solutions to improve the degree of male reproductive health.
\end{abstract}

Keywords : Riders, Reproductive, Online 


\section{PENDAHULUAN}

Makin pesatnya kemajuan zaman serta luas dan beragam pekerjaan yang ada di masyarakat maka kebutuhan alat transportasi juga makin meningkat. Kecenderungan peningkatan jumlah kendaraan bermotor dapat mengakibatkan kualitas udara makin menurun. Semakin meningkatnya jumlah kendaraan bermotor di jalanan ibu kota-kota besar dengan berbagai merk dan tipe akan meningkatkan konsumsi pemakaian bahan bakar minyak dan menimbulkan efek pencemaran udara, kenaikan konsumsi BBM sangat wajar jika melihat data Gabungan Industri Kendaraan Bermotor Indonesia (Gaikindo) menyatakan jumlah penjualan kendaraan bermotor meningkat cukup signifikan sejak empat tahun terakhir. Kendaraan bermotor merupakan salah satu sumber pencemar udara hampir di seluruh kota besar dunia, gas-gas beracun yang dikeluarkan dari jutaan knalpot kendaraan setiap harinya menimbulkan masalah serius di banyak negara salah satunya Indonesia, kendaraan berbahan bakar bensin menjadi salah satu sumber pencemar udara terbesar melebihi industri dan rumah tangga. ${ }^{1}$

Masalah serius yang dihasilkan dari emisi gas buang kendaraan bermotor dapat berupa gangguan fungsi reproduksi pria, antara lain terganggunya kesuburan pria. Terutama Timbal $(\mathrm{Pb})$ merupakan logam toksik yang mempengaruhi fertilitas pada pria. Kesuburan pria dapat berupa penurunan kualitas sperma sehingga kesulitan memiliki anak. ${ }^{2,3}$

Komunitas pengemudi ojek online merupakan salah satu komunitas dengan risiko gangguan kesehatan reproduksi pria yang sangat potensial. Pengemudi ojek online bisa menghabiskan waktu 8-10 jam dengan mengendarai motor dan paparan terus menerus dengan buangan gas emisi bahan bakar. Menyadari potensi masalah yang mungkin muncul pada mereka, para pengemudi ojek online ini berupaya untuk mengajukan permohonan untuk dilakukan upaya promotif kesehatan reproduksi pria bagi mereka, oleh Bagian Biologi Fakultas Kedokteran Universitas Sriwijaya. Oleh karena hal tersebut, Bagian Biologi 
merespon permintaan tersebut dengan membuat kegiatan upaya promotif kesehatan reproduksi pria melalui kegiatan ceramah, diskusi dan tanya jawab.

\section{TINJAUAN PUSTAKA}

Kendaraan bermotor menghasilkan $85 \%$ dari seluruh pencemaran udara yang terjadi. Emisi yang dikeluarkan kendaraan bermotor menghasilkan berbagai polutan seperti Karbon Monoksida (CO), Hidrokarbon (HC), Oksida Nitrogen (NOx), Oksida Sulfur (SOx), partikulat dan Timbal $(\mathrm{Pb})$. . $^{4-6}$

Efek buruk timbal pada sistem reproduksi pria meliputi: Spermatogenesis abnormal (penurunan jumlah dan motilitas), berkurangnya libido, fungsi prostat abnormal, kerusakan kromosom, perubahan serum testosteron dan infertilitas. Timbal asetat menyebabkan penurunan fungsi organ reproduksi pria yang signifikan serta terjadinya perubahan jaringan testis dalam pola histologis testis. Penurunan kualitas spermatozoa akibat paparan timbal karena timbal dapat menembus atau melewati blood testis barrier. ${ }^{7,8}$

Efek toksik akibat akumulasi timbal dalam tubuh dapat mengakibatkan perubahan proses biokimia dan histopatologis pada testis dan epididimis pada tikus setelah diberi timbal dosis toksik per oral selama 3 bulan. Timbal asetat yang diberikan secara oral kepada tikus jantan dewasa pada paparan 273 atau $819 \mathrm{mg} / \mathrm{L}$ menyebabkan penurunan yang signifikan dalam berat organ reproduksi, pengurangan jumlah sperma, penurunan motilitas dan viabilitas sperma, penurunan yang signifikan dalam produksi sperma, kualitas sperma memburuk dan kadar testosteron serum menunjukkan penurunan steroidogenesis..$^{9,10}$

\section{METODE}

Kegiatan upaya promotif kesehatan reproduksi pria ini dilaksanakan dengan Teknik penyuluhan, berupa ceramah, diskusi dan tanya jawab. Sasaran subyek kegiatan promotif ini ialah laki-laki usia reproduktif kelompok berisiko dalam hal ini pengemudi ojek motor sebanyak 30 orang di daerah Ilir Barat I dan Ilir Timur I. 
Edukasi kesehatan (penyuluhan) dan pemberian Buku Saku Kesehatan Reproduksi dilakukan dengan pemberian informasi melalui ceramah dan diskusi serta pemberian buku saku kesehatan reproduksi kepada pengemudi ojek tentang dampak asap kendaraan bermotor terhadap kesehatan reproduksi pria serta upaya promotif dan preventif untuk pemeliharaan kesehatan reproduksi. Disertai dengan aksi pembagian sejumlah masker yang dapat digunakan saat berkendara sebagai tindakan antisipasi dan pemeliharaan kesehatan. Peserta juga diberikan suplemen kesehatan untuk meningkatkan stamina pria.

\section{HASIL \& PEMBAHASAN}

Pada kegiatan penyuluhan dapat terlihat peserta yang hadir memiliki antusias yang tinggi ditandai beberapa peserta yang mengajukan pertanyaan dan diskusi terkait materi penyuluhan maupun masalah kesehatan yang dialaminya. Pertanyaan pun beragam sekitar siklus reproduksi pria dan upaya promotif dan preventif apa saja yang dapat dilakukan untuk menjaga kesehatan.

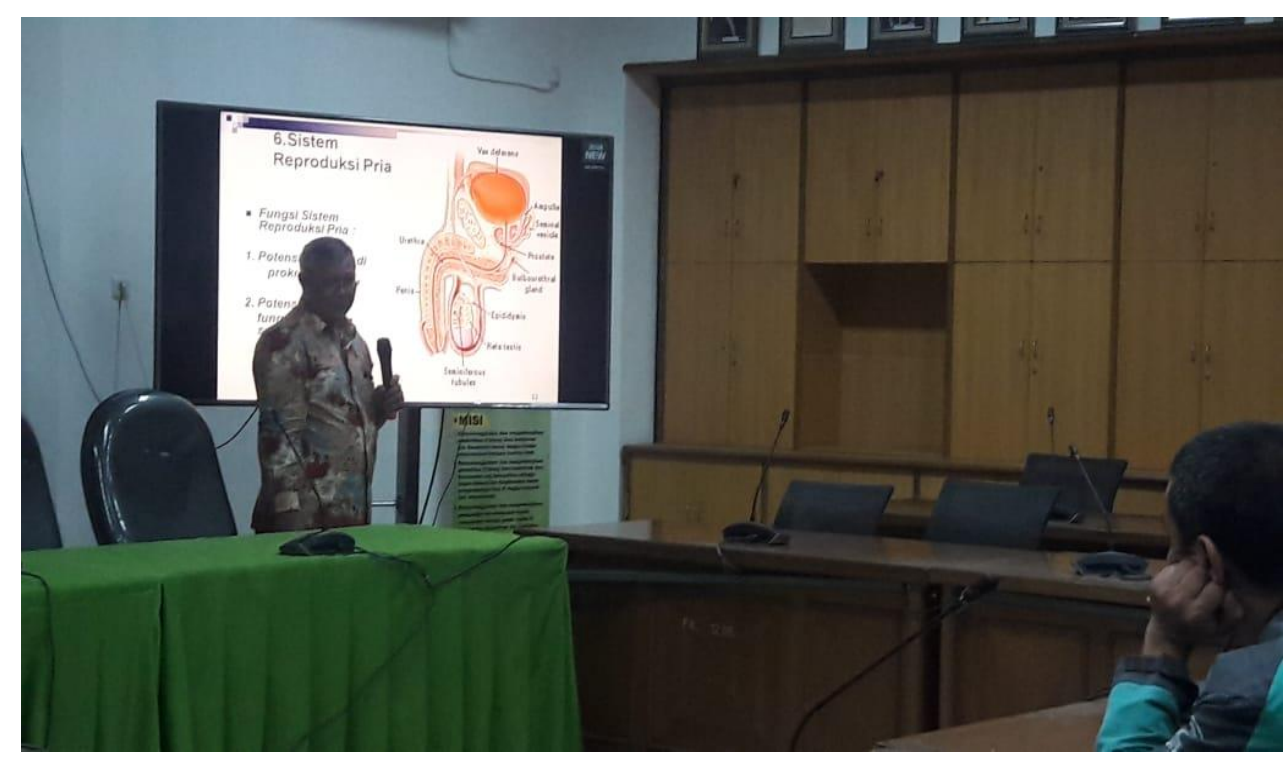

Gambar 1. Pemateri memberikan penyuluhan kepada peserta 


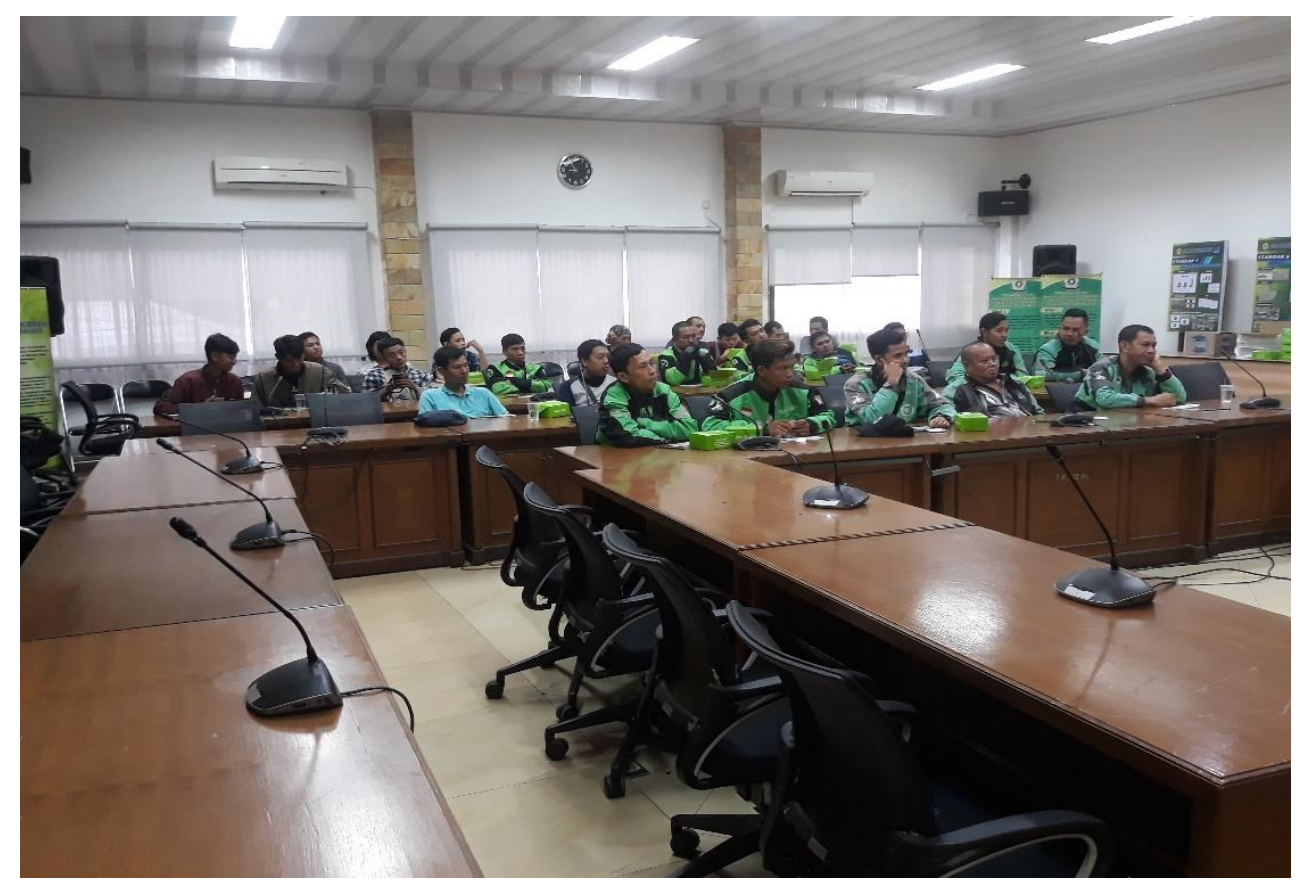

Gambar 2. Peserta terlihat begitu antusias memperhatikan materi penyuluhan yang diberikan

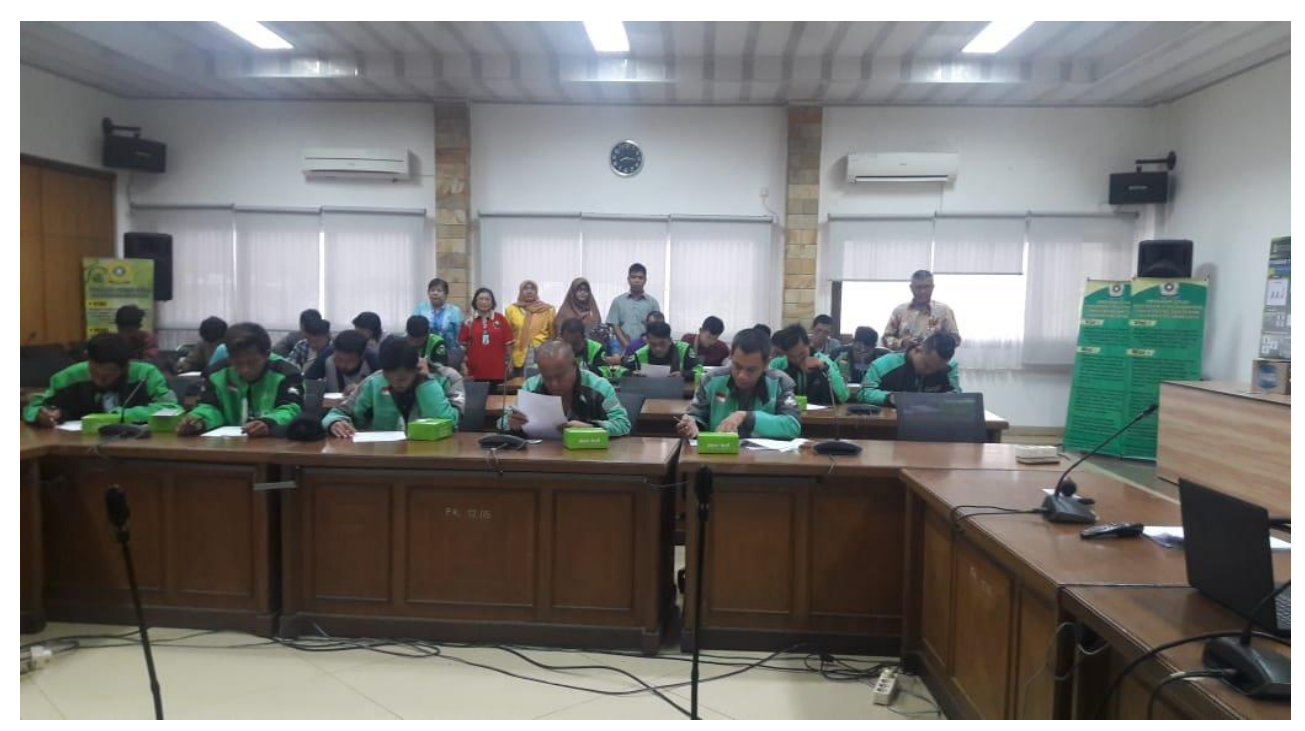

Gambar 3. Peserta tampak serius membaca buku panduan 
Komunitas pengemudi ojek online merupakan kelompok berisiko terhadap paparan emisi gas buang bahan bakar, mengingat waktu mereka berkerja sebagai ojek online berkisar 8-10 jam perhari. Emisi gas buangan bahan bakar merupakan salah satu oksidan poten yang berperan dalam inisiasi stress oksidatif pada berbagai organ, salah satunya pada organ reproduksi, testis. Stress oksidatif yang terjadi di testis tentunya akan mengganggu fungsi dari sel-sel yang terletak di testis. Sel Sertoli dan Leydig merupakan sel utama yang berperan dalam maturasi sperma. Stress oksidatif pada sel utama ini, akan menyebabkan terjadinya kematian dari sel Sertoli dan Leydig. Kematian sel-sel utama ini akan menyebabkan terganggunya proses pembentukkan sperma. Tentunya hal ini akan menyebabkan berkurangnya kemampuan reproduksi dari kelompok berisiko ini.

Upaya preventif dan promotif penting dilakukan secara optimal pada kelompok berisiko ini. Penyuluhan yang dilakukan pada kegiatan ini merupakan salah satu upaya promotif. Selain itu, edukasi bagi para komunitas ojek online untuk menggunakan masker selama kegiatan di jalan raya penting di edukasi kan kepada komunitas ini. Penggunaan masker diyakini mampu mengurangi paparan gas dan zat berbahaya yang terdapat banyak di jalan raya.

Selain itu, perlu dilakukan upaya preventif dengan penggunaan suplemen guna menjaga kualitas fungsi organ reproduksi. Suplemen dengan potensi sebagai anti oksidan merupakan modalitas preventif penting yang harus diedukasikan. Sebagaimana pada penyuluhan ini dieduksikan menggunakan herbal vitafortem, dengan komposisi Purwoceng, Tribulus dan Pimpinella. Dimana ketiga bahan utama tersebut telah teruji untuk menghambat proses stress oksidatif sehingga mampu meningkatkan kualitas pembentukkan sperma.

Pada akhir kegiatan para peserta memberikan ucapan terima kasih sehubungan dengan kegiatan pengabdian yang telah diberikan. Peserta merasakan banyak sekali manfaat yang didapatkan setelah mengikuti kegiatan penyuluhan ini diantaranya mendapatkan informasi dan pendidikan kesehatan khususnya mengenai kesehatan 
reproduksi pria yang selama ini mereka belum tahu serta meningkatkan kesadaran untuk menjaga dan memelihara kesehatan dan rutin memeriksakan kondisi kesehatan.

\section{SIMPULAN}

Kegiatan promotif ini menambah wawasan dan pengetahuan pengemudi ojek tentang dampak asap kendaraan bermotor terhadap kesehatan reproduksi pria serta meningkatkan kewaspadaan dan kesadaran untuk selalu memakai alat pelindung diri setiap berkendara, memelihara kesehatan dengan pola hidup sehat serta rutin memeriksakan diri ke fasilitas kesehatan terdekat.

\section{Referensi}

1. Anjum M.R, Sainath S.B, Suneetha Y, Reddy P.S. Lead acetate induced reproductive and paternal mediated developmental toxicity in rats. Ecotoxicol. Environ. Saf. 2011;74(4):793799.

2. Batra N, Nehru B, Bansal MP. Influence of lead and zinc on rat male reproduction at biochemical and histopathological levels. J.Appl. Toxicol. 2001. 21:507-12.

3. Benoff S, Jacob A, Hurley IR. Male infertility and environmental exposure to lead and cadmium. Hum Repro 2000; 6(2): 107-21.

4. Elgawish R.A.R, Abdelrazek H.M. Effects of lead acetate on testicular function and caspase-3 expression with respect to the protective effect of cinnamon in albino rats. Toxicol. Rep. 2014;1:795-801.

5. Flora S.J. Arsenic-induced oxidative stress and its reversibility. Free Radic. Biol. Med. 2011;51(2):257-281.

6. HIFERI. 2013. Konsensus penanganan infertiltas. Himpunan Endokrinologi Reproduksi dan fertiltas Indonesia.

7. Naha N, Chowdhury AR. Toxic effect of lead on human spermatozoa: A study among pigment factory workers. Indian J Occitt>Environ Med.2005. 9(3):118-123.

8. Practice Committee of the American Society for Reproductive Medicine. Definitions of infertility and recurrent pregnancy loss: a committee opinion. Fertility and sterility. 2013;99(1):63. https://doi.org/10.1016/j.fertnstert.2012.09.023 PMid:23095139.

9. Senkey, L.S., Jansen, F. dan Wallah, S. 2011. Tingkat pencemaran udara co akibat lalu lintas dengan model prediksi polusi udara skala mikro. Jurnal Ilmiah Media EngineeringVol 1, No 2, Hal 119-126.

10. World Health Organization. WHO manual for the standardised investigation and diagnosis of the infertile couple. Cambridge: Cambridge University Press, 2000. 